\title{
The Development Of Children Expressive Languages Viewed From Parental Care
}

\author{
Balgis Nur Fauzani, Siti Masitoh, Sri Setyowati \\ Universitas Negeri Surabaya \\ Surabaya, Indonesia \\ balgis_fauzani@yahoo.co.id
}

\begin{abstract}
This research aims to analyze the development of expressive language of children in terms of parental care. This research uses a descriptive qualitative research design. Informants in this study are children and parents. Data collection techniques in this study are observation techniques, interview techniques and documentation techniques. The results of this study indicate that development of expressive language can develop with the tendency of democratic parenting. In the result of this study, it can be explained that the development of expressive language can develop with the tendency of democratic parenting. In parenting democracy, the parents pay more attention to the opinions of children, giving the freedom that remains controlled in the child so that when made a mistake can be immediately given advice to the children and listen to the complaints of children. In this study explained that the parents' influence to accommodate children's language development, as evidenced by the interaction between parents and reciprocal children.
\end{abstract}

Keywods - Expressive Language Development, Parent Parenting Patterns.

\section{INTRODUCTION}

Early childhood is the next generation of this country. The quality of generation is the hope of every parent and society. Therefore, we are as educators or parents have a major role for children. Hope for the child is the child grow and develop according to stage of its development. The family also has an important role in giving effort to all aspects of child growth. A family is the first place a child will learn and know his personality as a social being.

Based on Permendikbud Number 137 Year 2014 about early childhood education standard there is a standard level of child development achievement consisting of 6 aspects of development. Aspects of that development include religious and moral values, cognitive, physical motor, language, emotional social and art. Language development is of particular concern in a research study, because language can affect the lives of children in the future.
The early childhood experience grows in various components in terms of physical, emotional, cognitive and language, because at an early age the growth and development of the child's brain reaches about $80 \%$ and $20 \%$ is the rest in adulthood later. Therefore, in the golden age is expected children get the right stimulation through an education [1].

The early childhood education is essentially an effort and action by parents and educators who aim to provide care and create a safe and comfortable environment for children. Children are given the opportunity to explore with their learning environment. Children can explore and conduct an experiment gradually and repeatedly so that children can hone all their potential and intelligence. A good environment impacts on giving children experience and opportunities to explore thoroughly. The child has a unique personality and the uniqueness of the child is adjusted according to the stage of child development.

In the process of providing education to children in schools, the home environment is supported fully. The role of the parent includes the opportunity for the child to express and communicate actively at home. Parents give their children time to talk about their experiences at school. An appropriate communication between parents and child is done by communicating directly, not using a phone or written message. By speaking directly the child's language skills will develop.

According to Badudu, the language is a means of communication between members of society which consists of individuals who express their thoughts, feelings, and desires. Basically, the language is a sound system that is used to collaborate, interact, identify themselves and the sound is arbitrary [2]

Huilt and Howard explained that the language in the form of symbols in the abstract and innate in mind. The capacity of a person to use different languages, this capacity can be expressed in the form of speech, writing, or movement [3]. Whereas according to Patmonodewo [4], language 
is understood as a complex and systematic system of language. According to Hildayani et al [3], stimulation can enrich the child's treasury in a good environment. It is expected that parents and teachers can collaborate in providing stimulation for the development of the language of children can develop optimally. Meanwhile, according to Syaodih [5], language development is a development that needs to be controlled by children because this development is an important development. Not all children will develop well in this development because of the limitations that exist, the child's limitations in expressing the language verbally and non verbally correctly, these conditions can hamper the development of children, so that language skills need to get stimulated properly. One of sharpening the ability of children is by telling the experience in school to the parents. In other words, how can a child develop his spoken language in expressive language, expressing verbally and non-verbally. According to states that expressive language is as stated by Dhieni [6].

The problems of expressive language development of each kindergarten are different. This occurs in group A children in TKM NU 126 Islamiyah Ujungpangkah Gresik. The developmental aspects of the language of one child with another are quite different. It can be seen in the learning activities. Some children still seem less able to speak. The child has not been able to express the language verbally or non-verbally.

Based on observations on November 20, 2017 , it is known that some problems related to the language of children is very less. Children tend not to be able to express the language properly. They need a proper way for the development of expressive language children develop according to their age. Some efforts to be done are to provide fun activities to stimulate the potential that exists in children.

The development of expressive language of the child can also be related to parental parenting. Parents or families are the smallest unit in society that has a role as the primary foundation of child development and the influence of the development of children is the school and the environment around the child. So, the positive and negative of a family will be very decisive how the life pattern of children both for the present and future. In addition, family conditions that are less open to a problem that occurs will result in the lack of good communication, both between parents and parents with children. Attention is the main thing parents should give to children, because with the attention of the child is more open to the parents, both open with big problems faced and small problems. How parents pay attention to children will have an impact on the development of children. For that parents must have a positive parenting pattern in educating their children according to the pattern of care as well as aspects of its development.

There are several kinds of parenting, according to Hurlock there are three types of parenting, namely: 1) Authoritarian is the way parents by giving rules to children and force children to do something according to the wishes of parents, desires and expectations of the children themselves are given limits. 2) Democratic parent gives many opportunities to the child so that the child can be independent and not be challenged to others. 3) Permissive is the child is given freedom in determining what is desired and the attitudes of parents who are just as observers [6].

In fact, parents apply different parenting styles to their children. This happens because of differences in social status, habits and culture that exist around the residence. Each applied parenting pattern has advantages and disadvantages of each. In the village community Ujungpangkah Gresik, people have a tendency of one of the pattern of care that has been mentioned. Many false parenting practices occur such as lack of active parent role in educating children's growth at home due to the business or work of the parents. In the village of Ujungpangkah Gresik, the majority of its citizens are seeking employment abroad or can be abbreviated as TKI (Indonesian Tenaga Kerja). The main purpose of parents working away from their children is in order to make their children get the feasibility of life in the future. The solution taken by both parents for a child left by a father or mother working as a migrant worker is one of working to become a migrant worker and one of the parents keeping a child at home with his grandmother or close family.

Several previous studies, related to parental parenting have an impact on the development of gross motor and social emotional in children group B in TKM NU 7 Pongangan Gresik. The study was conducted in 2017 by Jannatul Ma'wa. The researcher provide parenting to parents about the adoption of good parenting for the development of children, especially on the development of rough motor and social emotional.

Based on a preliminary interview on November 21, 2017 conducted by teachers at TKM NU 126 Islamiyah Ujungpangkah Gresik, there were more than 2 children at the age of 4-5 years who were treated only with 1 parent. One of the child's parents works as a migrant worker whose language development has not developed according to his age. The child reveals what is meant by pointing something, the child throws the toy if his or her desire is not met, and angry when the teacher does not understand what is meant or desired by the child. It is also supported by the observation as proving what is stated by the teacher. 
Relating to the context, the researcher took the research location in group A at TKM NU 126 Islamiyah Ujungpangkah Gresik. The reason why the researcher chose group A in TKM NU 126 Islamiyah Ujungpangkah Gresik as the research subject is that kindergarten has more than 2 children aged 4-5 years whose one parent works as TKI, so it can be assumed that the whole pattern care can be taken equally. In addition, the problem of language development of children is also a lot. Conditions are seen in some children who are quiet, cannot express opinions and convey what is meant to others. These characteristics become one of the basis for researcher to research at TKM NU 126 Islamiyah Ujungpangkah Gresik.

\section{RESEARCH METHODS}

This research includes qualitative descriptive research because the research will be conducted to describe the phenomenon of receptive language development and expressive language of children in terms of parenting patterns in TKM NU 126 Islamiyah Ujungpangkah Gresik. The information giver acting as the source and data of the information must be eligible, which is the source data in the research is the parent and child of class A group of children aged 4-5 years in TKM NU 126 Islamiyah Ujungpangkah Gresik.

Selection of data sources in the study is based on the principle of the subject who mastered the problem, have data, and willing to provide complete and accurate information. This research was conducted at TKM NU 126 Islamiyah Ujungpangkah Gresik which located in West Setro street RT 02 RW 08 Pangkah Kulon Ujungpangkah Gresik because it is one kindergarten that has various characteristic so it can be assumed that the whole pattern of parenting can be taken evenly. In addition, child language development issues are also commonly found in these kindergartens.

The collection can be done in various settings, various sources, and various ways that can be done with methods of observation, interviews, and documentation. Test the validity of the data is the author to test the credibility (degree of trust). Credibility serves to improve and demonstrate the level of confidence in data or discoveries achieved [7] Test of credibility in this research is by using data triangulation technique.

Technique of data analysis in this research is done since before plunge into the field, observation, during the implementation of research in field, and after finished research in field. This research data is obtained from interviews, observation and documentation. The data analysis is done by organizing the data obtained into a category, describing data into units, analyzing important data, compiling or presenting data in accordance with research problems in the form of reports and make conclusions for easy to understand.

Data analysis techniques according to is an activity in analyzing qualitative data [8]. The qualitative data is the source of a broad, wellgrounded description, and contains an explanation of the processes occurring in the local sphere. 1) Data Collection (Data Collection) is a collection of data or data collection that is collecting data in the location of research by doing observations, interviews, and documentation by determining data collection strategies that are considered appropriate and to determine the focus and deepening of data in the process of data collection. The process of obtaining the data from the field is done by using research instruments such as interviews, literature study, and documentation. 2) Data Condensation refers to the process of selecting, simplifying, abstracting, and transforming data close to the whole of the field records in writing, interview transcripts, documents, and other empirical materials. The data obtained in the field is quite a lot so there is a need for detailed and detailed records. Summarize, select the essentials, focus on the important things, look for the theme and pattern. Data condensation is a sensitive thinking process that performs intelligence and breadth and into higher insights. 3) Data Presentation (Data Display) is an organizational, uniting of information that enables inferences from action. Data presentation helps in understanding what has happened. The presentation of data is done after the reduction is completed or summarized. In the presentation of data is done through narrative text and matrix type, so by looking at the presentation of the data then what happens in the field can be understood and analyzed further. 4) Drawing and Verifying Conclusion is done because the initial statement is still temporary, and will change if there is no strong evidence to support the next data collection stage. But if the conclusions raised in the early stages are supported by strong and valid evidence then the conclusion put forward is a credible conclusion. The conclusions may not appear until the data collection ends, depending on the size of the collection of field notes, encodings, storage and retrieval methods used.

Selection of data sources in the study is based on the principle of the subject who mastered the problem, have data, and willing to provide complete and accurate information. This research was conducted at TKM NU 126 Islamiyah Ujungpangkah Gresik which located in West Setro street RT 02 RW 08 Pangkah Kulon Ujungpangkah Gresik because it is one kindergarten that has various characteristic so it can be assumed that the whole pattern of parenting can be taken evenly. In addition, child language development issues are also commonly found in these kindergartens. 


\section{RESEARCH AND DISCUSSION RESULTS}

In the result of this study, it can be explained that the development of expressive language can develop with the tendency of democratic parenting. In parenting democracy parent pay more attention to the opinions of children, giving the freedom that remains controlled in the child so that when made a mistake can be immediately given advice to the children and listen to the complaints of children. Authoritarian parenting shows no ability to develop language according to the age of the child due ti the pressure that is given by the parent to always follow the wishes of parents, obey that the parent want without seeing the will and opinion of the child and the demands of parents demanding perfection of children. While the permissive parenting pattern shows the child is given freedom in determining what is desired and the attitudes of parent who are just as observers. In this study explained that parent influence to accommodate children's language development, as evidenced by the interaction between parent and reciprocal children

\section{CONCLUSION}

Based on the results of research and discussion, parental care greatly affect the development of expressive language of the children. Parents or families are the smallest unit in society that has a role as the primary foundation of child development and the influence of the development of children is the school and the environment around the child. So, the positive and negative of a family will be very decisive how the life pattern of children both for the present and future. In the process parents have an effect on the development of expressive language of the child. Children development can develop well and slow depend on parental care. There are parenting patterns commonly used by parents include democratic parenting, permissive parenting patterns and authoritarian parenting patterns in group A children have different results.

\section{REFERENCES}

[1] M. P. I. Suyadi, Psikologi Belajar PAUD. Yogyakarta: Pedagogia, 2010.

[2] N. Dhieni, L. Fridani, A. Muis, and G. Yarmi, "Metode pengembangan bahasa," 2014.

[3] R. Hildayani, M. Sugianto, R. Tarigan, and E. Handayani, "Psikologi perkembangan anak," 2014.

[4] S. Patmonodewo, Pendidikan anak prasekolah. Rineka Cipta bekerjasama dengan Departemen Pendidikan \& Kebudayaan, 2000.

[5] E. Syaodih, "Bimbingan di taman kanakkanak," Jakarta: Depdiknas, p. 11, 2005.

[6] N. Dhieni, Metode Pengembangan Bahasa. 2007.

[7] L. J. Moleong, "Metodologi Penelitian Kualitatif edisi revisi," PT Remaja Rosdakarya Offset, Bandung, 2007.

[8] M. B. Miles, A. M. Huberman, and J. Saldana, "Qualitative data analysis: A methods sourcebook. 3rd." Thousand Oaks, CA: Sage, 2014. 